Ambiente \& Água - An Interdisciplinary Journal of Applied Science
ISSN 1980-993X - doi:10.4136/1980-993X
www.ambi-agua.net
E-mail: ambi.agua@gmail.com

\title{
Removal of odorous sulphur compounds from industrial gases by biotrickling filters
}

\author{
doi:10.4136/ambi-agua.1848
}

Received: 21 Jan. 2016; Accepted: 17 May 2016

\author{
Vincenzo Torretta ${ }^{1}$; Marco Schiavon ${ }^{2}$; Enrico Anselmo Papa ${ }^{1}$, Paolo Caruson ${ }^{3}$; \\ Andrea G. Capodaglio ${ }^{4 *}$ \\ ${ }^{1}$ Università degli Studi dell'Insubria, Varese, Italy \\ Department of Biotechnologies and Life Sciences \\ ${ }^{2}$ Università degli Studi di Trento, Trento, Italy \\ Department of Civil, Environmental and Mechanical Engineering \\ ${ }^{3}$ Air Clean Srl, Rho, Milano, Italy \\ ${ }^{4}$ Università degli Studi di Pavia, Pavia, Italy \\ Department of Civil Engineering and Architecture \\ "Corresponding author: e-mail: capo@unipv.it, \\ vincenzo.torretta@uninsubria.it, marco.schiavon@unitn.it, \\ enricoanselmo.papa@uninsubria.it, paolo.caruson@aircleansrl.com
}

\begin{abstract}
A pilot plant for the treatment of Sulphur-based odorous gases was installed in a line of a phosphoric acid plant located in Skhira, Tunisia. The air pollution control system train consisted of a first stage, including a chemical scrubber operating with an alkaline solution containing caustic soda, followed by a two-stage biotrickling filter (BTF) filled with Mytilus edulis shells. This study evaluated the performance of the dual-stage BTF in removing hydrogen sulphide $\left(\mathrm{H}_{2} \mathrm{~S}\right)$, sulphur dioxide $\left(\mathrm{SO}_{2}\right)$ and dimethyl sulphide (DMS) from the phosphoric acid reactor's exhaust air current. Concentrations of $\mathrm{H}_{2} \mathrm{~S}, \mathrm{SO}_{2}$ and DMS at the inlet of the two-stage BTF were 10-30 ppm, $<1-20 \mathrm{ppm}$ and 16-30 ppm, respectively. All of the respective concentrations at the outlet of the biological step were $<1 \mathrm{ppm}$, except for the $\mathrm{H}_{2} \mathrm{~S}$ in the outlet during the first day of operation (10 ppm). Removal efficiencies were generally higher than $95 \%$ for all compounds, and remained high even with an increase of the off-gas flow rate. Mass-removal capacity was at least $2.0 \mathrm{~g} \mathrm{~m}^{-3} \mathrm{~h}^{-1}, 0.5 \mathrm{~g} \mathrm{~m}^{-3} \mathrm{~h}^{-1}$ and $6.2 \mathrm{~g} \mathrm{~m}^{-3} \mathrm{~h}^{-1}$, for $\mathrm{H}_{2} \mathrm{~S}, \mathrm{SO}_{2}$ and DMS, respectively. The removal efficiencies of the process were satisfactory, especially considering the already low inlet concentrations, due to the high quality of the raw phosphate used.
\end{abstract}

Keywords: hydrogen sulphide, odor abatement, phosphoric acid production.

\section{Remoção de odores de compostos sulforosos de gases industriais por filtros biotrickling}

\section{RESUMO}

Uma estação piloto para o tratamento de gases odoríferos à base de enxofre foi instalado em uma linha de uma fábrica de ácido fosfórico localizada em Skhira (Tunísia). A estação piloto é constituída por um primeiro estágio que inclui um scrubber químico que usa uma 
solução alcalina à base de soda cáustica. O scrubber é seguido por um filtro biotrickling (BTF) de duplo estádio, preenchido com conchas Mytilus edulis. O objetivo deste trabalho é avaliar o desempenho do BTF na remoção do ácido sulfídrico $\left(\mathrm{H}_{2} \mathrm{~S}\right)$, dióxido de enxofre $\left(\mathrm{SO}_{2}\right)$ e sulfureto de dimetilo (DMS) contidos no efluente do reactor de ácido fosfórico. As concentrações de $\mathrm{H}_{2} \mathrm{~S}$, DMS e $\mathrm{SO}_{2}$ na entrada do BTF de duplo estádio foram 10-30 ppm, $<1-20$ ppm e 16-30 ppm, respectivamente. Todas as respectivas concentrações na saída do tratamento biológico foram <1 ppm, com a exceção da concentração de $\mathrm{H}_{2} \mathrm{~S}$ durante o primeiro dia de funcionamento $(10 \mathrm{ppm})$. As eficiências da remoção foram geralmente $>95 \%$ para todos os compostos e resultaram altas também após o aumento do fluxo do efluente gasoso. As capacidades de eliminação de $\mathrm{H}_{2} \mathrm{~S}, \mathrm{SO}_{2}$ e DMS foram $>2,0 \mathrm{~g} \mathrm{~m}^{-3} \mathrm{~h}^{-1}, 0,5 \mathrm{~g} \mathrm{~m}^{-3} \mathrm{~h}^{-1}$ e $6,2 \mathrm{~g} \mathrm{~m}^{-3} \mathrm{~h}^{-1}$, respectivamente. Apesar das baixas concentrações de entrada, principalmente devidas à alta qualidade do fosfato bruto, a instalação piloto mostrou resultados satisfatórios, tendo em vista o seu redimensionamento e a sua aplicação a uma escala maior.

Palavras-chave: abatimento de odores, ácido sulfídrico, produção de ácido fosfórico.

\section{INTRODUCTION}

Exposure to odorants is more a nuisance than an hazard to human health. However, prolonged exposure to odorants may cause adverse reactions ranging from emotional stress, such as anxiety, headache, or depression, to physical symptoms, such as eye irritation, respiratory problems, nausea or vomiting (Capodaglio et al., 2002; Shareefdeen and Singh, 2004). For these reasons, industrial activities that emit odorous compounds need appropriate removal systems in order to limit their presence in exhaust gases.

Control of pollution in large air flows with low concentrations of pollutants (generally $<100 \mathrm{ppm}$ ) is generally not economically viable when removal technologies require large amounts of fuel (electric energy), or when chemicals and adsorbents are adopted, due to the low achievable efficiencies (Hunter and Oyama, 2014). For this reason, the application of biologically-based technologies, which turn out to be more cost-effective than conventional ones (e.g., activated carbon adsorption, thermal or catalytic oxidation, absorption, selective catalytic or non-catalytic reduction), is becoming a popular alternative for industrial air pollution control.

Among biological technologies, biotrickling filters (BTFs) have recently gained increased attention due to their comparatively low cost and energy efficiency. In particular, BTFs have proven very effective in the treatment of industrial air streams (Rada et al., 2014), and have shown several advantages compared to the more common biofilters. These advantages are their limited size, longer life, lower pressure drop with subsequent lower power consumption, easy control of temperature, $\mathrm{pH}$, salt concentration and metabolite accumulation, wide range of treatable pollutants, greater stability of operation and better atmospheric dilution of the plume (Xue et al., 2013). BTFs have been widely tested and applied in the treatment of exhaust air pollutants from pharmaceutical (Chen et al., 2006), paint (Mathur and Majumder, 2008), refinery (Viotti et al., 2015) and livestock industries (van Groenestijn and Kraakman, 2005), as well as wastewater (Lebrero et al., 2014) and solid waste treatment facilities (Gutierrez et al., 2014). BTFs are reactors partly filled with inert materials, such as lava rock, shells, and plastic spheres or rings, which serve as a physical support for the growth of biomass. Water is sprayed at the top of the reactor, creating a liquid biofilm on the filler for the absorption of pollutants, providing the microorganisms with the required nutrients and removing excess sludge or decomposition products from the reactor by scouring. The water is collected at the bottom of the reactor and recirculated back. Therefore, both pollutant absorption into the biofilm and biodegradation occur in BTFs. 
A pilot treatment line for the removal of odorous sulphur gases, including hydrogen sulphide $\left(\mathrm{H}_{2} \mathrm{~S}\right)$, sulphur dioxide $\left(\mathrm{SO}_{2}\right)$ and dimethyl sulphide (DMS), was established at a phosphoric acid production facility in Skhira, Tunisia. Phosphoric acid is primarily used in fertilizer production and, secondarily, in the production of synthetic detergents, animal feed and pesticides. In this application, phosphoric acid is obtained by a wet process, consisting of the attack of ground phosphate rocks with sulphuric acid, the filtration of phosphoric acid from calcium sulphate (a byproduct of the chemical reaction), and the concentration of the phosphoric acid to the desired level. The chemical reaction leads to the formation of carbon monoxide, nitrogen oxides, $\mathrm{SO}_{2}$, hydrogen fluoride, ammonia, $\mathrm{H}_{2} \mathrm{~S}$ and DMS gases.

The adopted air pollution control system was designed to remove sulphur pollutants by means of a scrubber followed by a dual-stage BTF, and was operated for two months on site. This paper evaluates the performance of the dual-stage BTF in degrading the $\mathrm{H}_{2} \mathrm{~S}, \mathrm{SO}_{2}$ and DMS contained in the phosphoric acid reactor's off-gas. The paper presents the biological processes used in the test, the operating and testing procedures, and the results achieved in the abatement of these compounds.

\section{MATERIALS AND METHODS}

The treatment system studied is shown in Figure 1 and consists of:

- a chemical scrubber, operating with an alkaline solution for $\mathrm{SO}_{2}$ reduction and $\mathrm{H}_{2} \mathrm{~S}$ partial abatement;

- a dual-stage BTF, downstream of the chemical scrubber, for the removal of the remaining sulphur odorous compounds;

- water recirculation pumps;

- an off-gas centrifugal pump;

- a control cabinet.

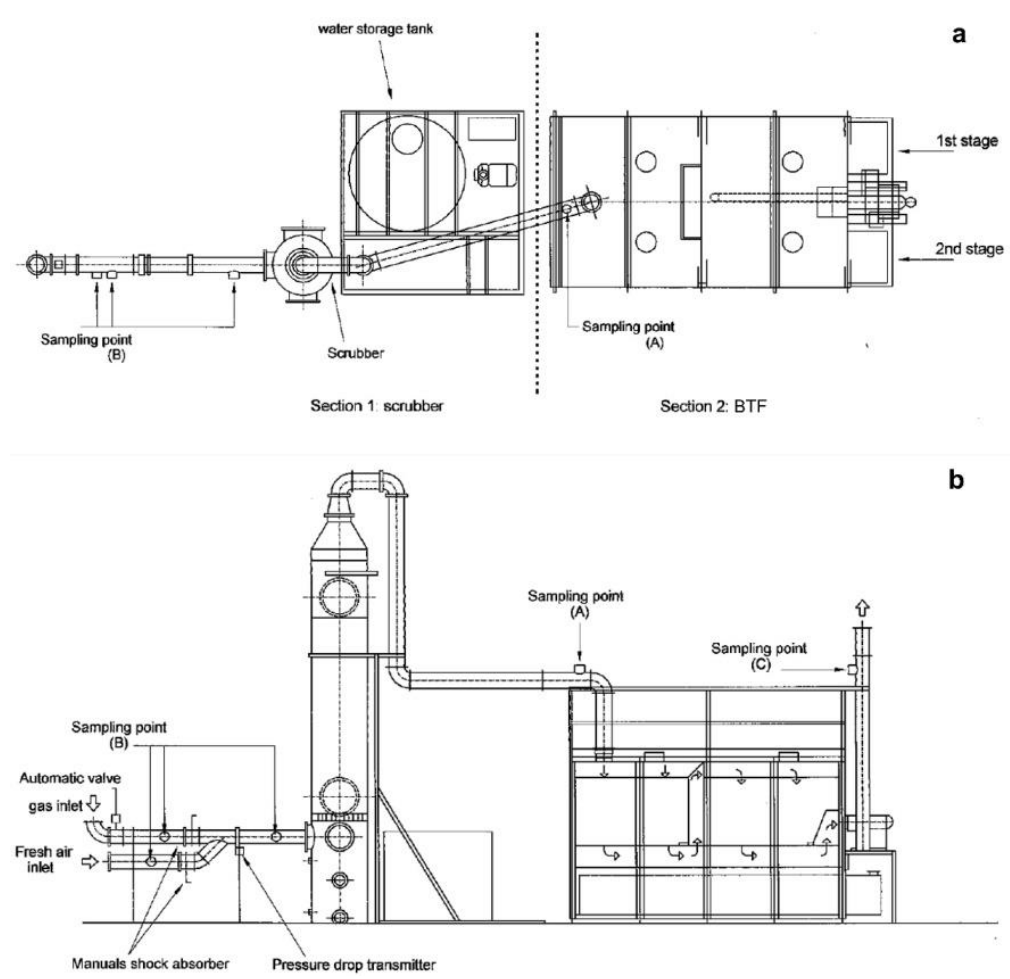

Figure 1. Exhaust air plant views: $a$ ) horizontal and $b$ ) vertical, with indication of sampling points. 
The exhaust air under treatment is drawn by a centrifugal blower, located downstream of the entire system. The blower operates with a power of $3 \mathrm{~kW}$, allowing a maximum flow rate of $1800 \mathrm{Nm}^{3} \mathrm{~h}^{-1}$. Air passes first through the scrubber, and reaches the BTF unit at a temperature lower than $45^{\circ} \mathrm{C}$, a relative humidity around $80-100 \%$ and solid particle content lower than $20 \mathrm{mg} \mathrm{m}^{-3}$. Throughout the whole experimental period, both the scrubber and the dual-stage BTF were operated continuously (24/7).

\subsection{Scrubber operation}

The scrubber used in this system consists of a vertical polypropylene cylinder with internal diameter of $0.8 \mathrm{~m}$ and height of $6.3 \mathrm{~m}$. The scrubber operates with alkaline washing of caustic soda $(\mathrm{NaOH}$ solution $<30 \% \mathrm{v} / \mathrm{v}))$.

The main role of the chemical scrubber is to absorb the soluble pollutants in the exhaust gas stream into water, resulting in attenuation of the $\mathrm{H}_{2} \mathrm{~S}$ and $\mathrm{SO}_{2}$ peak concentrations. In addition, due to its buffering capacity, the alkaline $\mathrm{NaOH}$ washing solution allows for the control of the $\mathrm{pH}$ of the gas prior to the biological treatment. The scrubber also serves as a backup system to control gas temperature and to protect the biological stage.

The washing solution is introduced from the top of the scrubber through spray nozzles, flowing by gravity through the absorption column to the bottom, where it is collected in a reservoir (diameter of $1.55 \mathrm{~m}$ and height of $0.33 \mathrm{~m}$ ). The reservoir is equipped with a tap for $\mathrm{NaOH}$ addition, and another for water replenishment, ensuring a constant level and concentration of the washing solution in the tank. The washing solution is recirculated to the top of the scrubber with a pump, while the exhaust gas flows counter-currently from the bottom to the top of the absorption column, which contains plastic fillers with large specific surface area to improve the contact between the gas and liquid phases, thus enhancing chemical exchange. This, combined with a high ratio between liquid and gas flows, results in a high elimination capacity of the incoming pollutants. Finally, a high-efficiency droplet separator ensures good aerosol retention before transition to the biological stage.

\subsection{Dual-stage BTF operation}

The unit consists of a dual-stage biological filter and could be considered a biological washing tower. The incoming air from the chemical scrubber is passed vertically through an area filled with calcareous sea shells, continuously humidified by the water recirculated within the system via a centrifugal pump.

The filling material is a bed of natural shells belonging to blue mussels of the Mytilus edulis species, pre-treated prior to installation by an exclusive process (Monashell ${ }^{\circledR}$, patented). The filter bed has different functions, such as supporting the growth of the microorganisms that biologically oxidize DMS, $\mathrm{H}_{2} \mathrm{~S}$ and sulphuric acid; supplying additional nutrients to the biomass; humidity retention; forming a surface where pollutants can be absorbed; and stabilizing the $\mathrm{pH}$. The latter is made possible through chemical reactions between the filter bed itself and the sulfates in the air stream. The Mytilus edulis shells are rich in calcium carbonate, present high affinity with weak acids, and provide a high buffering power to the system. The choice of this filling material offers several economical and process-related advantages: from an economic perspective, it is a recovered waste material and is thus available at low cost (compared to the costs required for its disposal); from the biological perspective, it facilitates absorption, since many odorous compounds are not easily soluble in the natural state. An additional advantage is low operating costs; for example, less water is necessary for $\mathrm{pH}$ restoration than in a bioscrubber, since $\mathrm{pH}$ is controlled by the filter bed itself.

The dual-stage unit consists of a modular bioreactor with a volume of $17 \mathrm{~m}^{3}$, where the filling material occupies a volume of $8 \mathrm{~m}^{3}$, placed within a container with a flat roof, all 
supported by a concrete platform. The recirculation of the washing solution is supported by two pumps, each with a power of $1.1 \mathrm{~kW}$, and connected with two nozzles working at the pressure of $0.8 \mathrm{Bar}$, with total flowrate of about $20 \mathrm{~L} \mathrm{~min}^{-1}$. The treated emissions are released to the atmosphere through a stack (diameter of $0.2 \mathrm{~m}$ ), providing a maximum outlet velocity of $16 \mathrm{~m} \mathrm{~s}^{-1}$.

In the first stage, the recirculated water sprayed on the top of the filter bed flows through the filling material and exits through a PVC pipe, collecting the water to repeat the cycle. The first-stage effluent air is sent to the second BTF stage, characterized by separate circulation water and spray systems, where the cycle is repeated. The water levels in the storage tanks of both stages are controlled with level sensors.

In order to keep the solution clean and avoid a $\mathrm{pH}$ decrease of the recirculation water in the second stage, part of the washing solution is periodically wasted through a time-controlled $\left(4 \mathrm{~s} \mathrm{~h}^{-1}\right)$ solenoid valve. An equal amount of water from the first stage is automatically transferred to the second stage, and fresh make-up water is drawn into the first stage tank from the supply network.

The BTF was initially seeded with a bacterial inoculum of Thiosphaera pantotropha, a selected bacterial culture capable of assimilating reduced-sulphur compounds.

\subsection{Test Procedure}

The pilot system was operated continuously for about 10 weeks. During this period, chemical, physical and microbiological analyses were carried out on the off-gas, in addition to microbiological analyses on the cell count of the mesophilic bacteria, both in the water solution and in the filtering material.

Off-gas analyses included temperature and $\mathrm{H}_{2} \mathrm{~S}$, DMS, $\mathrm{SO}_{2}$ concentrations; the latter were measured at the sampling points located upstream of the dual-stage BTF (A) and at the outlet $(\mathrm{C})$. These are compounds of interest due to their abundance in the exhausts and to the low odor threshold values, equal to $0.00041 \mathrm{ppm}, 0.0030 \mathrm{ppm}$ and $0.87 \mathrm{ppm}$, respectively (Nagata, 2003). Tests were performed by varying the gas flow rate between 1200 and $1500 \mathrm{Nm}^{3} \mathrm{~h}^{-1}$, corresponding to an empty bed residence time (EBRT) between 16 and $24 \mathrm{~s}$. In addition, the off-gas temperature was monitored at $\mathrm{A}, \mathrm{C}$ and at a sampling point located upstream of the scrubber (B). The pressure drop between B and A and between A and C was measured also. Dräger tubes (Drägerwerk AG \& Co. KGaA, Germany) were used for the analysis of $\mathrm{H}_{2} \mathrm{~S}$, DMS and $\mathrm{SO}_{2}$ concentrations. Analyses of recirculation water of both stages concerned $\mathrm{pH}$, sulphate $\left(\mathrm{SO}_{4}{ }^{2-}\right)$ concentration, and temperature. $\mathrm{SO}_{4}{ }^{2-}$ is an oxidation product of $\mathrm{H}_{2} \mathrm{~S}, \mathrm{SO}_{2}$ and mercaptans in the circulation water (Zhang et al., 2015); its concentration was measured with colorimetric strips (Merck KGaA, Germany). The presence of $\mathrm{SO}_{4}{ }^{2-}$ in the BTF recirculation water is an indicator of biodegradation effectiveness.

During the ordinary running period, air concentrations of $\mathrm{H}_{2} \mathrm{~S}, \mathrm{SO}_{2}$ and DMS, and $\mathrm{pH}$, $\mathrm{SO}_{4}{ }^{2-}$ content and the temperature of the $\mathrm{BTF}$ recirculation water were sampled at least once per week.

\section{RESULTS AND DISCUSSION}

The combined scrubber-BTF system was initially tested at different airflow rates, with a maximum of $1800 \mathrm{Nm}^{3} \mathrm{~h}^{-1}$, as reported in Table 1 . The purpose of this initial test was the quantification of the pressure drop at increasing flow rates. The total pressure drop, measured between the sampling points $\mathrm{B}$ and $\mathrm{C}$, ranged from 70 to $245 \mathrm{~mm} \mathrm{H}_{2} \mathrm{O}$ when the air flow rate increased from 1200 to $1800 \mathrm{Nm}^{3} \mathrm{~h}^{-1}$. This airflow increase induced an increase in the pressure drop over the BTF that was anyway limited to between 10 and $45 \mathrm{mmH}_{2} \mathrm{O}$. 
In addition to the removal of the initial pollutants, a positive effect deriving from the scrubber unit operation is the reduction of the off-gas temperature from $44.0-53.6^{\circ} \mathrm{C}$ in $\mathrm{B}$ to 32.0-36. $7^{\circ} \mathrm{C}$ in A (Table 1), favoring the growth of the biofilm.

After inoculation, the dual-stage BTF was started up. During the tests, thanks to the replenishing scheme of the recirculation water, its $\mathrm{pH}$ never fell below 6.5, from a maximum of 7.5 (Table 2).

Table 1. Velocity, temperature and pressure drop of the exhaust gas measured at sampling points A, B and $\mathrm{C}$ with different gas flow rates.

\begin{tabular}{|c|c|c|c|c|c|c|c|c|}
\hline \multirow{3}{*}{$\begin{array}{l}\text { Gas flow rate } \\
{\left[\mathrm{Nm}^{3} \mathrm{~h}^{-1}\right]}\end{array}$} & \multicolumn{3}{|c|}{$\begin{array}{l}\text { Velocity } \\
{\left[\mathrm{m} \mathrm{s}^{-1}\right]}\end{array}$} & \multicolumn{3}{|c|}{$\begin{array}{c}\text { Temperature } \\
{\left[{ }^{\circ} \mathrm{C}\right]}\end{array}$} & \multicolumn{2}{|c|}{$\begin{array}{l}\text { Pressure drop }\left[\mathrm{mmH}_{2} \mathrm{O}\right] \\
\text { scrubber |biofilter }\end{array}$} \\
\hline & \multicolumn{3}{|c|}{ Sampling point } & \multicolumn{3}{|c|}{ Sampling point } & \multicolumn{2}{|c|}{ Sampling points } \\
\hline & B & $\mathrm{A}$ & $\mathrm{C}$ & B & A & $\mathrm{C}$ & B-A & A-C \\
\hline 1200 & 11.4 & 10.7 & 10.6 & 53.6 & 35.6 & 32.0 & 60 & 10 \\
\hline 1490 & 12.9 & 12.6 & 13.2 & 51.5 & 36.7 & 32.1 & 62 & 20 \\
\hline 1470 & 15.0 & 12.1 & 13.0 & 50.3 & 35.0 & 31.3 & 90 & 30 \\
\hline 1540 & 16.0 & 15.5 & 13.6 & 46.0 & 34.3 & 31.6 & 160 & 35 \\
\hline 1810 & 16.5 & 16.2 & 16.0 & 47.0 & 33.2 & 32.2 & 196 & 45 \\
\hline 1800 & 15.0 & 15.3 & 15.9 & 44.0 & 32.0 & 31.7 & 200 & 45 \\
\hline
\end{tabular}

Three days after the BTF start-up, the biological bed was fully active; however, an acclimation period of about four weeks was necessary to reach full efficiency (Table 3). The concentrations of $\mathrm{H}_{2} \mathrm{~S}$, DMS and $\mathrm{SO}_{2}$ at the inlet of the dual-stage BTF (sampling point A) were in the ranges between 10 and $30 \mathrm{ppm}, 16$ and $30 \mathrm{ppm},<1$ and $20 \mathrm{ppm}$, respectively. The respective concentrations at the outlet of the biological step (sampling point $\mathrm{C}$ ) were all $<1 \mathrm{ppm}$, except for the $\mathrm{H}_{2} \mathrm{~S}$ concentration during the very first day of operation (10 ppm). Removal efficiencies were generally higher than $95 \%$ for all compounds. Elimination rates were, at minimum, $2.0 \mathrm{~g} \mathrm{~m}^{-3} \mathrm{~h}^{-1}, 0.5 \mathrm{~g} \mathrm{~m}^{-3} \mathrm{~h}^{-1}$ and $6.2 \mathrm{~g} \mathrm{~m}^{-3} \mathrm{~h}^{-1}$, for $\mathrm{H}_{2} \mathrm{~S}, \mathrm{SO}_{2}$ and DMS, respectively. The analytical methodology used did not allow for the determination of concentrations < $1 \mathrm{ppm}$; therefore, the effective elimination rates may be higher than those here reported.

The removal efficiencies of the incoming pollutants were high even when higher off-gas flow rates were used. Concentration of $\mathrm{SO}_{4}{ }^{2-}$ in the $\mathrm{BTF}$ recirculation water ranged between 20 and $90 \mathrm{ppm}$, indicating the presence of microbial activity degrading sulphur compounds (Table 2).

Other BTF pilot- and laboratory-scale applications for the removal of sulphur compounds reported in the literature generally referred to higher inlet concentrations: Chen et al. (2006) worked with $\mathrm{H}_{2} \mathrm{~S}$ inlet concentrations about 10 times higher than those reported in this paper, obtaining removal efficiencies $>90 \%$ at an EBRT of 9 s. Removal efficiencies $>95 \%$, and elimination rates of about $50 \mathrm{~g} \mathrm{~m}^{-3} \mathrm{~h}^{-1}$ were obtained by a BTF operating with an EBRT of 29 s, and inlet concentrations 10 times higher than those observed here (Montebello et al., 2013). Biodegradation of $\mathrm{SO}_{2}$ was documented in a recent publication (Zhang et al., 2015) where a biofilter, operating with EBRT of $18 \mathrm{~s}$ degraded $\mathrm{SO}_{2}$ in an air stream at 100-200 ppm, showing a removal efficiency $>93 \%$ and a maximum elimination rate of $50.67 \mathrm{~g} \mathrm{~m}^{-3} \mathrm{~h}^{-1}$. DMS removal was the object of a study on a BTF application operating with EBRT of $120 \mathrm{~s}$, which achieved a removal efficiency $>90 \%$ and a maximum elimination rate of $7.2 \mathrm{~g} \mathrm{~m}^{-3} \mathrm{~h}^{-1}$, from an initial concentration of 117 ppm (Sercu et al., 2005). 
Table 2. Chemical and physical characteristics of the recirculation water.

\begin{tabular}{|c|c|c|c|c|c|c|c|c|c|c|c|c|c|c|c|c|c|c|}
\hline Day & \multicolumn{2}{|c|}{1} & \multicolumn{2}{|c|}{2} & \multicolumn{2}{|c|}{3} & \multicolumn{2}{|c|}{8} & \multicolumn{2}{|c|}{13} & \multicolumn{2}{|c|}{21} & \multicolumn{2}{|c|}{27} & \multicolumn{2}{|c|}{36} & \multicolumn{2}{|c|}{48} \\
\hline $\begin{array}{l}\text { Gas flow rate } \\
{\left[\mathrm{Nm}^{3} \mathrm{~h}^{-1}\right]}\end{array}$ & \multicolumn{2}{|c|}{1200} & \multicolumn{2}{|c|}{1200} & \multicolumn{2}{|c|}{1200} & \multicolumn{2}{|c|}{1200} & \multicolumn{2}{|c|}{1200} & \multicolumn{2}{|c|}{1470} & \multicolumn{2}{|c|}{1470} & \multicolumn{2}{|c|}{1480} & \multicolumn{2}{|c|}{1500} \\
\hline BTF stage & $1^{\text {st }}$ & $2^{\text {nd }}$ & $1^{\text {st }}$ & $2^{\text {nd }}$ & $1^{\text {st }}$ & $2^{\text {nd }}$ & $1^{\text {st }}$ & $2^{\text {nd }}$ & $1^{\mathrm{st}}$ & $2^{\text {nd }}$ & $1^{\mathrm{st}}$ & $2^{\text {nd }}$ & $1^{\text {st }}$ & $2^{\text {nd }}$ & $1^{\mathrm{st}}$ & $2^{\text {nd }}$ & $1^{\mathrm{st}}$ & $2^{\text {nd }}$ \\
\hline $\mathrm{pH}[-]$ & 7.3 & 7.3 & 7.2 & 7.3 & 7.3 & 7.2 & 7.4 & 7.5 & 7.3 & 7.4 & 7.2 & 7.0 & 7.0 & 6.5 & 6.8 & 6.6 & 7.0 & 6.6 \\
\hline $\mathrm{SO}_{4}{ }^{2-}[\mathrm{ppm}]$ & - & - & - & - & - & - & 60 & 60 & 20 & 20 & 60 & 30 & 30 & 90 & 30 & 30 & - & - \\
\hline $\begin{array}{l}\text { Temperature } \\
{\left[{ }^{\circ} \mathrm{C}\right]}\end{array}$ & 28.5 & 27.7 & 37.0 & 38.0 & 31.0 & 31.8 & 34.0 & 34.0 & 36.0 & 34.00 & 34.0 & 35.0 & 33.00 & 36.0 & 32.0 & 33.0 & 34.0 & 42.0 \\
\hline
\end{tabular}

Table 3. Pollutant concentrations measured at sampling points A, B and C during the operational period of exhaust-treatment plant.

\begin{tabular}{|c|c|c|c|c|c|c|c|c|c|c|c|c|c|c|c|c|c|c|}
\hline Day & \multicolumn{2}{|c|}{1} & \multicolumn{2}{|c|}{2} & \multicolumn{2}{|c|}{3} & \multicolumn{2}{|c|}{8} & \multicolumn{2}{|c|}{13} & \multicolumn{2}{|c|}{21} & \multicolumn{2}{|c|}{27} & \multicolumn{2}{|c|}{36} & \multicolumn{2}{|c|}{48} \\
\hline $\begin{array}{l}\text { Gas flow rate } \\
{\left[\mathrm{Nm}^{3} \mathrm{~h}^{-1}\right]}\end{array}$ & \multicolumn{2}{|c|}{1200} & \multicolumn{2}{|c|}{1200} & \multicolumn{2}{|c|}{1200} & \multicolumn{2}{|c|}{1200} & \multicolumn{2}{|c|}{1200} & \multicolumn{2}{|c|}{1470} & \multicolumn{2}{|c|}{1470} & \multicolumn{2}{|c|}{1480} & \multicolumn{2}{|c|}{1500} \\
\hline $\begin{array}{l}\text { at sampling } \\
\text { points }\end{array}$ & A & $\mathrm{C}$ & A & $\mathrm{C}$ & A & $\mathrm{C}$ & A & $\mathrm{C}$ & A & $\mathrm{C}$ & A & $\mathrm{C}$ & $\mathrm{A}$ & $\mathrm{C}$ & A & $\mathrm{C}$ & $\mathrm{A}$ & $\mathrm{C}$ \\
\hline $\mathrm{H}_{2} \mathrm{~S}$ [ppm] & 30 & 10 & 20 & $<1$ & 20 & $<1$ & 13 & $<1$ & 10 & $<1$ & 15 & $<1$ & 10 & $<1$ & 13 & $<1$ & 10 & $<1$ \\
\hline $\mathrm{SO}_{2}[\mathrm{ppm}]$ & 20 & 1 & 20 & $<1$ & 20 & $<1$ & $<1$ & $<1$ & $<1$ & $<1$ & $<1$ & $<1$ & $<1$ & $<1$ & 2 & $<1$ & - & - \\
\hline DMS [ppm] & - & - & - & - & - & - & 16 & $<1$ & 20 & $<1$ & - & - & - & - & - & - & - & - \\
\hline
\end{tabular}




\section{CONCLUSIONS}

The performance of a pilot air pollution control system, consisting of a chemical scrubber followed by a dual-stage BTF, was evaluated on the off-gas line of a phosphoric acid production plant in Skhira, Tunisia. Analyses were performed of the off-gas sulphur compounds, specifically, of $\mathrm{H}_{2} \mathrm{~S}, \mathrm{SO}_{2}$ and DMS concentrations upstream and downstream of the BTF.

Based on the results obtained during the unit operation, the dual-stage BTF resulted in the very satisfactory abatement of sulphur compounds, reaching removal efficiencies generally $>95 \%$, although inlet concentrations were already relatively low, compared to the values reported in similar studies. These were due to the high quality of the phosphate introduced into the phosphoric acid production reactor in the Skhira plant.

\section{REFERENCES}

CAPODAGLIO, A. G.; CONTI, F.; FORTINA, L.; PELOSI, G.; URBINI, G. Assessing the Environmental Impact of WWTP Expansion: Odour Nuisance and its Minimization. Water Science and Technology, v. 46, n. 4-5, 2002.

CHEN, J. M.; JIANG, L. Y.; SHA, H. L. Removal efficiency of high-concentration $\mathrm{H}_{2} \mathrm{~S}$ in a pilot-scale biotrickling filter. Environmental Technology, v. 27, n. 7, p. 759-766, 2006. http://dx.doi.org/10.1080/09593332708618687

GUTIERREZ, M. C.; SERRANO, A.; MARTIN, M. A.; CHICA, A. F. Odour in composting processes at pilot scale: monitoring and biofiltration. Environmental Technology, v. 35, n. 13-16, p. 1676-1684, 2014. http://dx.doi.org/10.1080/09593330.2014.880132

HUNTER, P.; OYAMA, S. T. Control of volatile organic compound emissions: Conventional and Emerging Technologies. New York: Wiley, 2014. 288 p.

LEBRERO, R.; GONDIM, A. C.; PÉREZ, R.; GARCÍA-ENCINA, P. A.; MUÑOZ, R. Comparative assessment of a biofilter, a biotrickling filter and a hollow fiber membrane bioreactor for odor treatment in wastewater treatment plants. Water Research, v. 49, p. 339-350, 2014. http://dx.doi.org/10.1016/j.watres.2013.09.055

MATHUR, A. K.; MAJUMDER, C. B. Biofiltration and kinetic aspects of a biotrickling filter for the removal of paint solvent mixture laden air stream. Journal of Hazardous Materials, v. 152, n. 3, p. 1027-1036, 2008. http://dx.doi.org/10.1016/j.jhazmat.2007.07.112

MONTEBELLO, A. M.; BEZERRA, T.; ROVIRA, R.; LAFUENTE, L.; GAMISANS, X.; CAMPY, S. et al. Operational aspects, $\mathrm{pH}$ transition and microbial shifts of $\mathrm{H}_{2} \mathrm{~S}$ desulfurizing biotrickling filter with random packing material. Chemosphere, v. 93, n. 11, p. 2675-2682, 2013. http://dx.doi.org/10.1016/j.chemosphere.2013.08.052

NAGATA, Y. Measurement of odor threshold by triangle odor bag method. In: JAPAN. Environmental Management Bureau. Odor measurement review. Kawasaki: Japan Environmental Sanitation Center, 2003. p. 118-127.

RADA, E. C.; RABONI, M.; TORRETTA, V.; COPELLI, S.; RAGAZZI, M.; CARUSON, P. et al. Removal of benzene from oil refinery wastewater treatment plant exhausted gases with a multi-stage biofiltration plant. Revista De Chimie, v. 65, n. 1, p. 68-70, 2014. 
SERCU, B.; NÚÑEZ, D.; AROCA, G.; BOON, N.; VERSTRAETE, W.; VAN LANGENHOVE, $\mathrm{H}$. Inoculation and start-up of a biotricking filter removing dimethyl sulfide. Chemical Engineering Journal, v. 113, n. 2-3, p. 127-134, 2005. http://dx.doi.org/10.1016/j.cej.2005.04.008

SHAREEFDEEN, Z; SINGH, S. Biotechnology for odor and air pollution control. Heidelberg: Springer, 2004. 409 p.

VAN GROENESTIJN, J. W.; KRAAKMAN, N. J. R. Recent developments in biological waste gas purification in Europe. Chemical Engineering Journal, v. 113, n. 2-3, p. 8591, 2005. http://dx.doi.org/10.1016/j.cej.2005.03.007

VIOTTI, P.; SCHIAVON, M.; GAVASCI, R.; CAPODAGLIO, A. G.. Removal of benzene and toluene from a refinery waste air stream by water sorption and biotrickling filtration. Revista Ambiente \& Água, v. 10, n. 4, p. 720-727, 2015. http://dx.doi.org/10.4136/ambi-agua.1764

XUE, N.; WANG, Q.; WANG, JU.; WANG, JI; SUN, X. Odorous composting gas abatement and microbial community diversity in a biotrickling filter. International Biodeterioration \& Biodegradation, v. 82, p. 73-80, 2013. http://dx.doi.org/ 10.1016/j.ibiod.2013.03.003

ZHANG, J.; LI, L.; LIU, J. Thermophilic biofilter for $\mathrm{SO}_{2}$ removal: Performance and microbial characteristics. Bioresource Technology, v. 180, p. 106-111, 2015. http://dx.doi.org/10.1016/j.biortech.2014.12.074 